\title{
ROLE OF A MOUSE MONOCLONAL IgE ANTIBODY IN PASSIVE TRANSFER OF IMMUNITY TO SCHISTOSOMA JAPONICUM INFECTION
}

\author{
SOMEI KOJIMA, TUENTA JANECHARUT, HIDEKAZU HATA \& MUNETOSHI NIIMURA
}

\author{
Department of Parasitology, Chiba University School of Medicine, Chiba 280, Japan
}

We have been able to produce a mouse monoclonal IgE antibody specific to an adult worm antigen extracted from Schistosoma japonicum $(S j)$. The antibody was able to elicit passive cutaneous anaphylaxis in the rat skin against $S j$ with the highest titer of $1: 256,000$ but did not crossreact with $\mathrm{S}$. mansoni antigen. The antibody recognized a 97-kDa molecule expressed on the surface of mechanically transformed schistosomula of S. japonicum. Passive transfer of the antibody into mice in the early stage of challenge infection resulted in a partial but significant reduction of recovery of adult worms. Induction of eosinophilia by an oral administration of embryonated eggs of Toxocara canis prior to challenge infection enchanced the reduction.

One of the characteristic immune responses to helminthic infections is IgE antibody production. It has been suggested that IgE antibodies may play a role in protective immunity to helminthic infections because this class of antibodies may be easily produced by Schistosoma mansoni infection in unsuitable hosts such as rats and because the antibodies may be detected around the period of the worm expulsion in the case of Nippostrongylus brasiliensis infection in the rat (Ogilvie, 1964).

However, there are controversial reports concerning the role of $\mathrm{IgE}$ antibodies in immunity against schistosome infections at least in vivo systems. James \& DeBlois (1986) have suggested that $\operatorname{IgE}$ antibodies are not essential for vaccine-induced resistance to $S$. mansoni infection, because SJL mice, low responders in terms of IgE antibody production ( $\mathrm{Vaz}$ et al., 1971; Kojima \& Ovary, 1975; Watanabe et al., 1976), were able to respond to vaccination with irradiated cercariae with significant resistance to challenge infection. This was also true in the case of $S$. japonicum infection in which a significant reduction of worm recovery was observed in B10.S $\left(\mathrm{H}-2^{\mathrm{s}}\right)$ strain of mice, a low responder in $\mathrm{IgE}$ antibody production to $S$. japonicum adult worm antigen (Sj) (Usawattanakul et al., 1982; Kaji et al., 1983). In contrast, Horowitz et al. (1982) have demonstrated that immunization of mice with

This work was supported in part by a gant from the U.S. - Japan Cooperative Medical Sciences Program and Grants 56870043, 60480160, and 61304037 from the Ministry of Education, Science and Culture. sonicated cercarial extracts of $S$. mansoni may result in induction of relatively efficient protection in association with production of a high titer of anti-cercarial IgE antibody.

To clarify whether the $\lg E$ antibody exerts a protective role in vivo, we have established a mouse hybridoma that produces $\operatorname{IgE}$ antibody specific to $S$. japonicum (Kojima et al., 1987). The present paper is to review our recent works and to further extend our observations on the enhancement of protective activity of the monoclonal IgE antibody in eosinophiliainduced mice.

\section{METHODS AND RESULTS}

Elicitation of passive cutaneous anaphylaxis (PCA) by monoclonal IgE antibody - The monoclonal $\mathrm{IgE}$ antibody designated as $\mathrm{SJ} 18 \epsilon .1$ was able to elicit PCA in the rat skin (Ovary et al., 1975) with the highest titer of $1: 256,000$ in ascitic form against $\mathrm{Sj}$, whereas the antibody did not react with $S$. mansoni antigen even at a dilution of $1: 10$.

Western blot analysis - Molecular weights of antigens recognized by $\mathrm{SJ} 18 \epsilon .1$ were determined by Western blotting (Towbin et al., 1979) in which rat monoclonal antibodies specific to mouse $\epsilon$-chain (generous gifts of Dr. T. Hirano of the Juntendo University, Tokyo) (Hirano et al., 1987) were used. Results indicated that the monoclonal $\operatorname{IgE}$ antibody SJ18E.1 recognized epitopes on molecules of $82,97,160$, and $200 \mathrm{kDa}$ when extract of $S$. japonicum adult pairs was electrophoresed 
under nonreduced condition. Under reduced condition, however, the antibody bound to major bands of 82 and $97 \mathrm{kDa}$. Moreover, the molecules of 82 and $160 \mathrm{kDa}$ were considered as those derived from female worms because they were not observed in another lot of antigen extracted from male worms. Further analysis revealed that the $97 \mathrm{kDa}$ molecule was also present in extract of mechanically transformed schistosomula of $S$. japonicum
(Fig. 1).

Binding of SJI8E 1 to the surface of schistosomula - Indirect immunofluorescence was carried out to examine the presence or absence of the antigenic target of the monoclonal antibody SJ $18 \epsilon .1$ on the surface of mechanically transformed schistosomula. Results indicated strong binding of the monoclonal antibody to the surface of $S$. japonicum schistosomula.

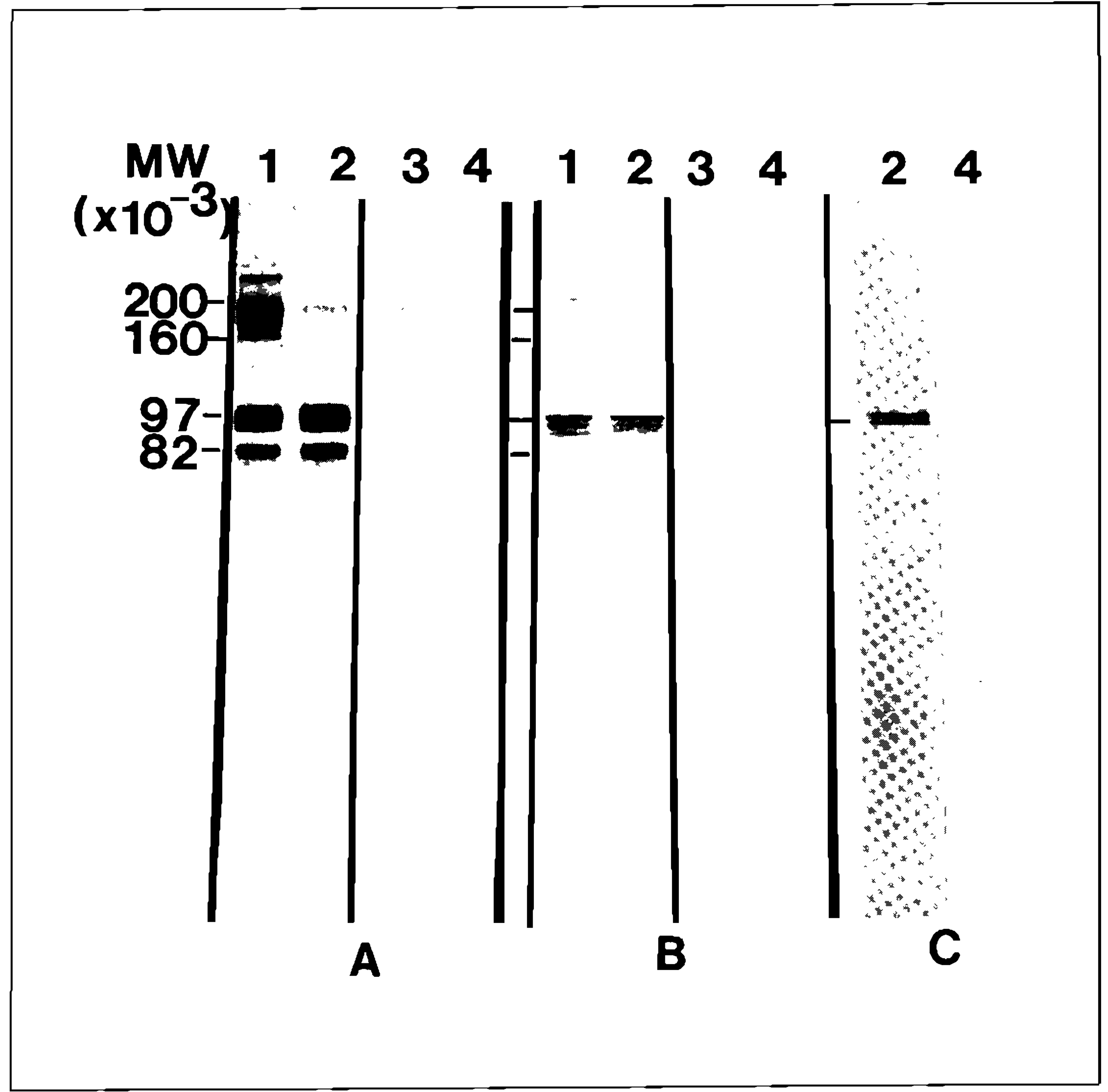

Fig. 1: Western blot analysis of Schistosome jeponicum antigens recognized by monoclonal IgE antibody SJ18 1 . Antigens prepared either from worm pairs obtained from mice (A), from male worms obtained from rabbits (B), or from mechanically transformed schistosomula (C), were subjected to SDS-PAGE under nonreduced (lanes 1 and 3 ) or reduced (lanes 2 and 4) condition. Nitrocellulose strips were incubated with monoclonal antibody SJ18E.1 (lanes 1 and 2) or normal mouse serum (lanes 3 and 4). For detection of binding of SJ18€.1, rat monoclonal anti-mouse IgE was used. 
Passive transfer of immunity - To examine whether or not the monoclonal IgE antibody is protective against $S$. japonicum infection in vivo, naive mice received i.p. $1 \mathrm{ml}$ each of $\mathrm{SJ} 18 \epsilon .1$, either in culture supernatant or ascites, on day -1 , day 0 , and day 2 of challenge infection. Portal perfusion was carried out 8 to 10 weeks after the infection. A significant reduction of worm recovery $(\mathrm{p}<0.05)$ was observed in mice that received the ascitic form of SJ18E.1 with a PCA titer of $1: 25,600$, as compared with the result in control mice treated with normal mouse serum (Fig. 2, experiment 1). The i.p. administration of the antibody with a low PCA titer $(1: 2,560)$ resulted in a partial reduction, whereas no reduction was observed in mice treated with another monoclonal IgE antibody with DNP specificity derived from hybridoma B.53 (Böttcher et al., 1980). Moreover, the passive transfer of SJ18E.1 was not effective for the protection if the antibody was given to mice in the postlung stage of the infection.

Involvement of SJI8E.1 in eosinophilmediated damage to schistosomula - Since SJ18E.1 binds to the surface of schistosomula, there is a possibility that eosinophil-mediated killing of schistosomula may occur in vitro in the presence of the antibody, as we have previously shown the killing of dinitrophenylated (DNP) schistosomula by using monoclonal anti-DNP IgE antibody (Kojima et al., 1985a, b). As expected, a significant cytotoxicity was observed when schistosomula were cocultured with peritoneal eosinophils from $N$. brasiliensis infected rats in the presence of $\mathrm{SJ} 18 \mathrm{\epsilon} .1$, as compared with a control in which the antibody was replaced by normal serum. On the other hand, eosinophil-mediated damage was not significant when monoclonal anti-DNP IgE antibody was used.

Enhancement of SJI8EI-dependent immunity by induction of eosinophilia - The results mentioned above suggest that eosinophils are involved as effector cells in the passive transfer of immunity. Therefore, the next experiment was designed to know the effect of eosinophilia on the protective activity of SJ18 1 .1. Eosinophilia was induced in mice by an oral administration of embryonated eggs of Toxocara canis 12 days prior to challenge infection according to the method described by Sugane \& Oshima (1980). The results are summarized in Fig. 3, indicating that the reduction of worm recovery was enhanced by the administration of $T$. canis eggs. A significant reduction was observed even in a group of mice transferred culture supernatant with a low PCA titer.

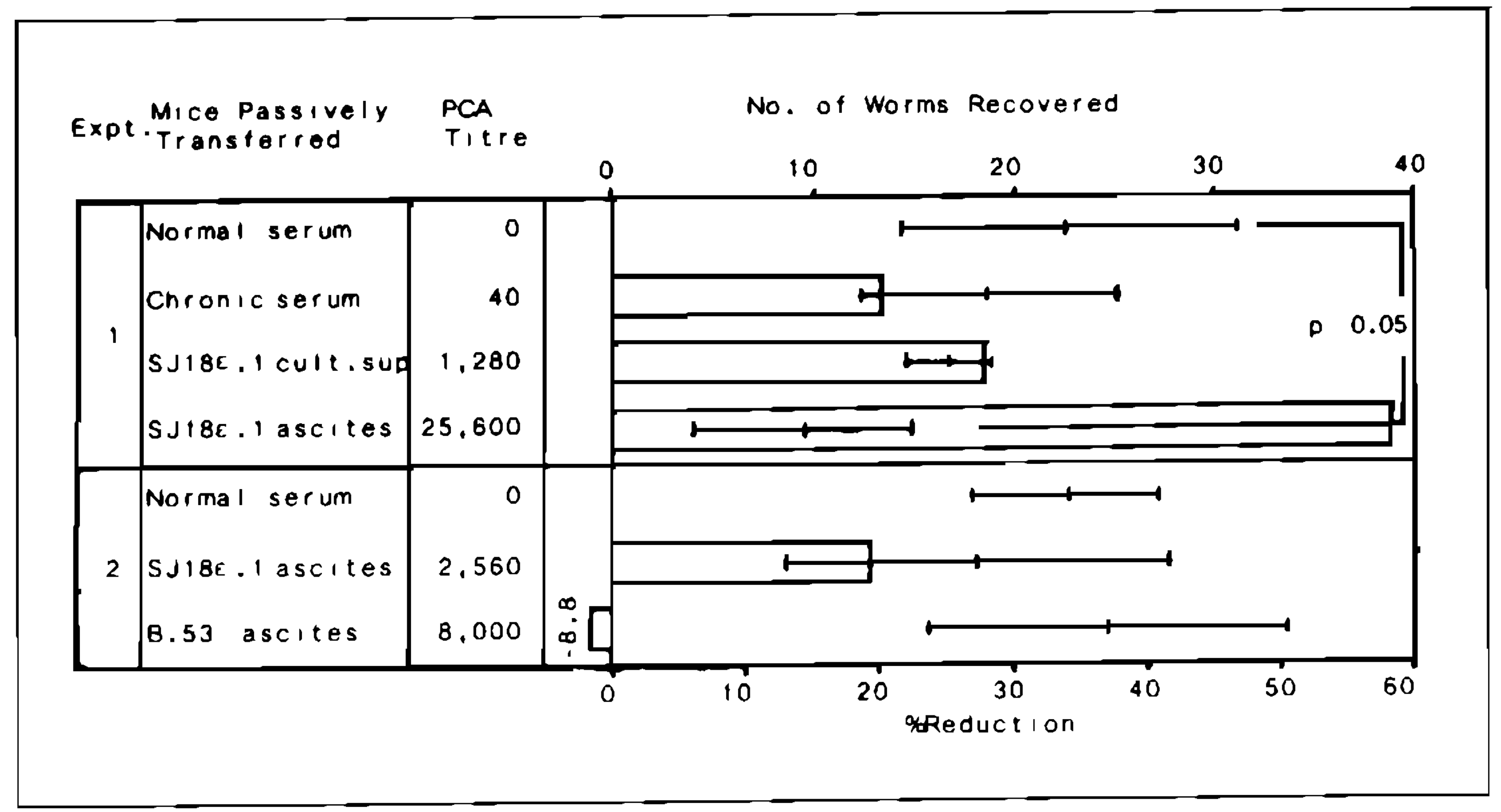

Fig. 2: Reduction of worm recovery by passive transfer of monoclonal IgE antibody SJ18E.1. A group of five mice received i. p. injections of $1 \mathrm{ml}$ each of either serum or monoclonal antibody listed in the column on days $-1,0$, and 2 . The mice were challenged with 50 cercariae of Schistosoma japonicum on day 0. 


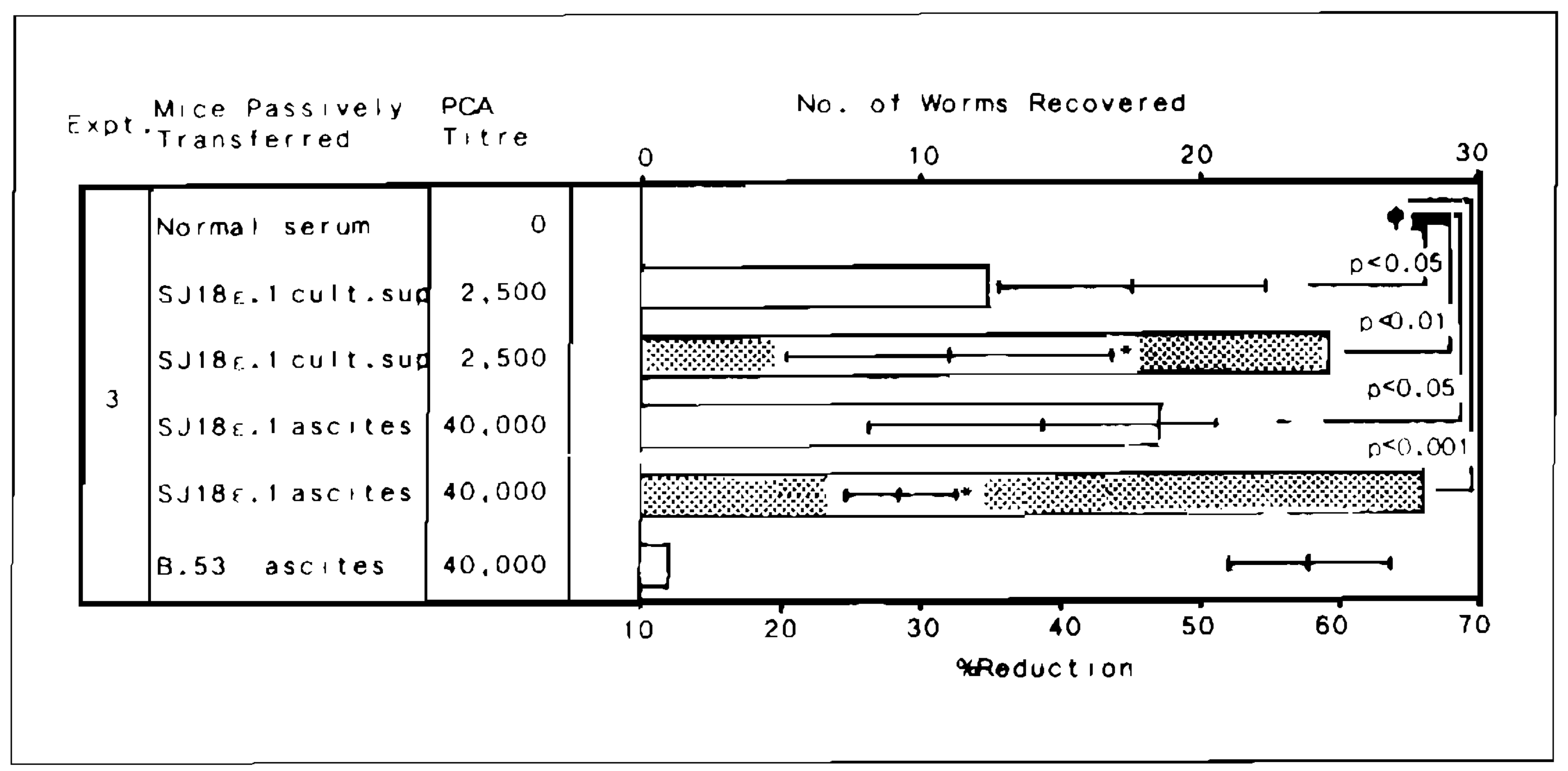

Fig. 3: Fffects of eosinophilia on passive transfer of immunity by monoclonal lgE antibody SJ186.1. A group of five mice, with (stippled bars) or without (open bars) eosinophilia which was induced by an oral administration of 500 embryonated eggs of Toxocara canis 12 days prior to challenge infection, recejved i. p. injections of $1 \mathrm{ml}$ each of either serum or monoclonal antibody listed in the column on days $-1,0$, and 2 . The mice were challenged with 40 cercariae of Schistosoma japonicum on day 0.

\section{DISCUSSION}

The results presented here suggest that $\operatorname{IgE}$ antibodies are involved in protective immunity against schistosome infection if the antibodies are properly produced as to bind to the surface molecule of the skin stage of schistosomula in vivo. However, a monoclonal $\operatorname{lgE}$ antibody raised against $S$. mansoni cercarial antigen did not confer protection against challenge infection, although the antibody was able to induce macrophage-mediated killing of schistosomula in vitro (Horowitz et al., 1983, 1985). Quite recently, another monoclonal IgE antibody to $S$. mansoni was produced by Capron and his colleagues (Verwaerde et al., 1987) and this antibody was shown to be involved in vitro killing of schistosomula mediated by macrophages, eosinophils, and platelets, although the antibody could not elicit PCA in the rat skin. Moreover, passive transfer of the monoclonal antibody into naive rats induced a significant level of protection against a challenge infection. The target antigen of the antibody was found to be a molecule of $26 \mathrm{kDa}$ present in released products of schistosomula.

Although our monoclonal $\lg E$ antibody binds to the $97 \mathrm{kDa}$ surface molecule of schistosomula and the antibody does confer protection against challenge infection in vivo, further studies will be needed for the characterization and purification of this particular target molecule for future works on vaccination.

\section{ACKNOWLEDGMENTS}

Grateful acknowledgment is made to the Organizing Committee of the International Symposium on Schistosomiasis for kind invitation and to Dr. Seiki Tateno of the Laboratorio de Imunopatologia Prof. Keizo Asami (LIKA) at the Federal University of Pernambuco for providing SK with an opportunity to attend the Symposium.

\section{REFERENCES}

BÖTTCHER, I.; ULRICH, M.; HIRAYAMA, N. \& OVARY, Z., 1980. Production of monoclonal mouse IgE antibodies with DNP specificity by hybrid cell lines. Int. Arch. Allergy Appl. Immunol., 61: 248-250.

HIRANO, T.; MIYAJIMA, H.; KITAGAWA, H.; WATANABE, N.; AZUMA, M.; TANIGUCHI, O.; HASHIMOTO, H.; HIROSE, S.; YAGITA, H.; FURUSAWA, S.; OVARY, Z. \& OKUMURA, K., 1988. Studies on murine IgE with monoclonal antibodies. I. Characterization of rat monoclonal anti-IgE antibodies and the use of these antibodies for determinations of serum $\operatorname{IgE}$ levels and for anaphylactic reactions. Int. Arch. Allergy Appl. Immunol., 85:47-54. 
HOROWITZ, S.; SMOLARSKY, M. \& ARNON, R., 1982. Protection against Schistosoma mansoni achieved by immunization with sonicated parasite. Eur. J. Immunol., 12: 327-332.

HOROWITZ, S.; TARRAB-HAZDAI, R.; ESHHAR, Z. \& ARNON, R., 1983. Anti-schistosome monoclonal antibodies of different isotype---correlation with cy totoxicity. EMBO J., 2: 193-198.

HOROWITZ, S.; BRENNER, V. \& ARNON, R., 1985. In vivo protection against $S$. mansoni infection by monoclonal antibodies. Immunol. Letters, 9: 69-73.

JAMES, S. L. \& DEBLOIS, L. A., 1986. Induction of protective immunity against Schistosoma mansoni by a nonliving vaccine. II. Response of mouse strains with selective immune defects. J. Immunol., 136: 3864-3871.

KAJI, R.; KAMIJO, T.; YANO, A. \& KOJIMA, S., 1983. Genetic control of immune responses to Schistosoma japonicum antigen. Parasite Immunol., 4: 25-35.

KOJIMA, S. \& OVARY, Z., 1975. Effect of Nippostrongylus brasiliensis infections on anti-hapten $\mathrm{IgE}$ antibody response in the mouse. I. Induction of carrier specific helper cells. Cell. Immunol., 15 . 274-286.

KOJIMA, S.; YAMAMOTO, N.; KANAZAWA, T.; SHIGEMATSU, H. \& OVARY, Z., 1985a. Enhancement of IgE-dependent eosinophil cytotoxicity to dinitrophenylated schistosomula by a nematode infection. Int. Arch. Allergy Appl. Immunol., 76:91-94.

KOJIMA, S.; YAMAMOTO, N.; KANAZAWA, T. \& OVARY, Z., 1985b. Monoclonal IgE-dependent eosinophil cytotoxicity to haptenated schistosomula of Schistosoma japonicum: enhancement of the cytotoxicity and expression of $F c$ receptors for IgE by Nippostrongylus brasiliensis infection. J. Immunol, 134: 2719-2722.

KOJIMA, S.; NIIMURA, M. \& KANAZAWA, T., 1987. Production and properties of a mouse monoclonal IgE antibody to Schistosoma japonicum. J. Immunol., 139: 2044-2049.

OGILVIE, B. M., 1964. Reagin-like antibodies in animals immune to helminth parasites. Nature, 204: 91-92.

OVARY, Z.; CAIAZZA, S. \& KOJIMA, S., 1975. PCA reactions with mouse antibodies in mice and rats. Int. Arch. Allergy Appl. Immunol., 48: 16-21.

SUGANE, K. \& OSHIMA, T., 1980. Recovery of large numbers of eosinophils from mice infected with Toxocare canis. Am. J. Trop. Med. Hyg., 29: $799-802$.

TOWBIN, H.; STAEHLIN, T. \& GORDON, J., 1979. Electrophoretic transfer of proteins from polyacrylamide gels to nitrocellulose sheets: procedure and some applications. Proc. Natl. Acad. Sci. USA, 76: $4350-4354$.

USAWATTANAKUL, W.; KAMIJO, T. \& KOJIMA, S., 1982. Comparison of recovery of schistosomula of Schistosoma japonicum from lungs of mice and rats. J. Parasitol., 68: 783-790.

VAZ, N. M.; PHILliPS-QUAGLIATA, J. M.; LEVINE, B. B. \& VAZ, E. M., 1971. H-2 linked genetic control of immune responsiveness to ovalbumin and ovomucoid. J. Exp. Med., 134: 1335-1348.

VERWAERDE, C.; JOSEPH, M.; CAPRON, M.; PIERCE, R. J.; DAMONNEVILLE, M.; VELGE, F.; AURIAULT, C. \& CAPRON, A., 1987. Functional properties of a rat monoclonal $\operatorname{lgE}$ antibody specific for Schistosoma mansoni. J. Immunol., 138: $4441-4446$. 